\title{
EFEK COKLAT DALAM MEMPERSINGKAT DURASI ILEUS PASCAOPERASI PADA LAPAROTOMI KARENA APENDISITIS PERFORATA
}

\author{
Yadi Pasinggi \\ Harsali Lampus \\ Hebert B. Sapan \\ Bagian Bedah Fakultas Kedokteran Universitas Sam Ratulangi Manado / \\ BLU RSUP Prof. Dr. R. D. Kandou Manado \\ Email: yadisakeus@gmail.com
}

\begin{abstract}
This study aimed to observe the influence of chocolate per oral aministered 6 hours post laparotomy in shortening the duration of postoperative ileus in patients with appendicitis perforata. Participants were 34 patients with perforated appendicitis who had laparotomy performed on them; 17 patients were given chocolate per oral meanwhile the others were controls. This grouping was obtained by using stratified random sampling with double blind technique. The results showed that chocolate administration 6 hours post laparotomy could shorten the duration of postoperative ileus with an average of 8,8 hours. This effect was significant for the occurence of the first flatus, but not for the first peristalsis and defecation.
\end{abstract}

Keywords: postoperative ileus, perforated appendicitis, chocolate

\begin{abstract}
Abstrak: Penelitian ini bertujuan untuk mengamati pengaruh coklat per oral yang diberikan sejak 6 jam pascaoperasi dalam mempersingkat durasi ileus pascaoperasi pada pasien yang menjalani laparotomi atas indikasi apendisitis perforata. Partisipan ialah 34 pasien apendisitis perforata yang menjalani laparotomi; 17 di antaranya diberi coklat dan 17 lainnya berperan sebagai kontrol. Pengelompokan dilakukan secara acak dengan teknik buta-ganda. Hasil penelitian memperlihatkan bahwa pemberian coklat sejak 6 jam setelah laparotomi dapat mempersingkat durasi ileus pascaoperasi hingga rata-rata 8,8 jam. Efek ini terlihat secara bermakna dalam mempercepat terjadinya flatus pertama (rata-rata lebih cepat 8,8 jam), namun tidak dalam hal bising usus pertama dan buang air besar pertama.
\end{abstract}

Kata kunci: ileus pascaoperasi, apendisitis perforata, coklat

Ileus pascaoperasi (IPO) merupakan pola abnormal pada motilitas saluran cerna yang terjadi setelah prosedur pembedahan, ditandai oleh mual, muntah, distensi abdomen, dan hambatan keluarnya flatus atau tinja. ${ }^{1}$ Gangguan ini menyertai 3-32\% pembedahan abdominal ${ }^{2}$ dan memperlambat pemulihan pasien karena berbagai gangguan saluran cerna yang membatasi toleransi pasien terhadap diet oral. ${ }^{3}$ Tertundanya pemulihan pasien juga dipengaruhi oleh efek psikologis negatif akibat memanjangnya masa hospitalisasi. ${ }^{4}$ Biaya penanganan IPO di AS dapat mencapai 1,5 triliun dolar per tahun. ${ }^{3}$

IPO yang terjadi dalam 24 jam setelah pembedahan merupakn konsekuensi logik dari pembedahan abdominal, namun durasi gangguan ini dapat memanjang pada pasien dengan latar belakang demografis dan riwayat medik tertentu, terutama pada pasien dengan apendisitis perforata. Gangguan ini sering disertai peritonitis yang memicu respons inflamasi maupun 
neurologik sehingga terjadi perlambatan motilitas saluran cerna. Ileus pada apendisitis perforata diperburuk oleh latar belakang demografis pasien yang umumnya berusia lanjut karena faktor degeneratif. ${ }^{2,5,6}$ Apendisitis pada usia lanjut memiliki gambaran klinis yang tidak khas sehingga sering menyebabkan keterlambatan berobat dimana pasien umumnya menjalani pembedahan akibat perforasi apendiks. ${ }^{7}$ Dengan demikian, potensi terjadinya IPO pada kondisi klinis seperti ini sangat besar karena faktor usia, peritonitis akibat perforasi, dan intervensi selama pembedahan abdominal.

Berbagai terapi alternatif dalam mempersingkat durasi IPO telah lama diteliti dan didokumentasikan, namun umumnya belum diterima secara luas dan belum dijadikan prosedur rutin dalam penanganan pasien pascaoperasi. Salah satu bahan alternatif yang dapat digunakan ialah coklat yang terbukti dapat mempercepat terjadinya bising usus dan flatus pertama. ${ }^{8,9}$ Meskipun demikian perlu dipertanyakan apakah makan coklat masih memberi hasil yang sama pada kasus-kasus dengan potensi IPO yang lebih tinggi seperti apendisitis perforata dimana ileus sudah terjadi sebelum pembedahan sehingga IPO yang terjadi sebenarnya merupakan resultan dari berbagai faktor yang saling menguatkan. ${ }^{1,5,7}$

Penelitian ini bertujuan untuk mengamati efek coklat secara khusus pada laparotomi karena apendisitis perforata dengan teknik acak buta-ganda. Bukti-bukti dari penelitian ini diharapkan dapat menjajaki lebih jauh dan menambah wawasan mengenai efek coklat dalam mempersingkat durasi IPO.

\section{METODE PENELITIAN}

Penelitian ini melibatkan 34 pasien apendisitis perforata yang menjalani laparatomi di RSUP Prof. Dr. R. D. Kandou Manado sejak bulan Nopember 2014 hingga jumlah tersebut tercapai. Pemilihan sampel dilakukan secara sederhana, kemudian sampel dibagi menjadi 2 kelompok (17 pasien yang menerima coklat dan 17 pasien kontrol) dilakukan secara acak dengan teknik butaganda. Pasien yang dilibatkan ialah semua pasien laparotomi karena apendisitis perforata yang berusia >18 tahun, menggunakan opioid serta analgesia umum, dan menandatangani informed consent. Pasien tidak dilibatkan atau dinyatakan gagal follow up bila meninggal, mengalami kelumpuhan yang bersifat upper motor neuron, mengalami penurunan kesadaran dengan risiko tersedak, laparatominya melibatkan reseksi usus atau pembuatan stoma, atau pasien dengan ketidaksetimbangan elektrolit yang berat (kadar natrium $<120 \mathrm{mmol} / \mathrm{L}$ atau $>145 \mathrm{mmol} / \mathrm{L}$ dan/atau kadar kalium $<2,5 \mathrm{mmol} / \mathrm{L}$ atau $>6 \mathrm{mmol} / \mathrm{L}){ }^{10}$

Sediaan coklat padat yang digunakan pada penelitian ini ialah Frey Extra Dark ${ }^{\mathrm{TM}}$ dari Chocolat Frey $\mathrm{AG}^{\circledR}$ Swis yang mengandung $85 \%$ dark chocolate. Sediaan coklat padat dipilih untuk memaksimalkan pengaruh inisiasi diet pada pasien pascaoperasi dan sediaan dark chocolate dipilih karena komposisi coklatnya terhadap bahan pelengkap lebih tinggi dibanding sediaan coklat lain. ${ }^{11}$ Setiap potong coklat padat memiliki bobot 35 gram dan pasien mengonsuminya setelah 6 jam pasca operasi sebanyak 3 kali sehari selama 3 hari. Setelah itu, setiap jam diamati terjadinya bising usus pertama, flatus pertama dan BAB pertama dan dicatat. Meskipun ketiga gejala/tanda tersebut sudah ada, pemeriksaan perjam tetap dilanjutkan untuk mengamati adanya muntah atau keluhan lain yang dapat berhubungan dengan pemberian coklat atau IPO itu sendiri. IPO dinyatakan berakhir bila 2 gejala berikut tidak ditemukan, yaitu muntah dan perut kembung, serta ditemukan minimal 2 dari 3 gejala/tanda berikut: bising usus pertama, flatus pertama, dan buang air besar pertama. Semua prosedur pasca-operasi rutin tetap berjalan selama masa pengamatan.

Dilakukan analisis deskriptif untuk menggambarkan karakteristik sampel. Uji 
hipotesis dilakukan dengan terlebih dahulu menganalisis normalitas sebaran data pada kedua kelompok. Uji-t untuk dua sampel independen akan ditempuh apabila data menyebar normal dan uji nonparametrik Mann-Whitney dilakukan bila data tidak menyebar normal.

\section{HASIL PENELITIAN}

Hingga bulan Juli 2015 telah terkumpul 34 sampel; sebagian sampel diperoleh dari RS lain di Kota Manado. Semua partisipan dapat menyelesaikan masa pengamatan selama 1-3 hari.

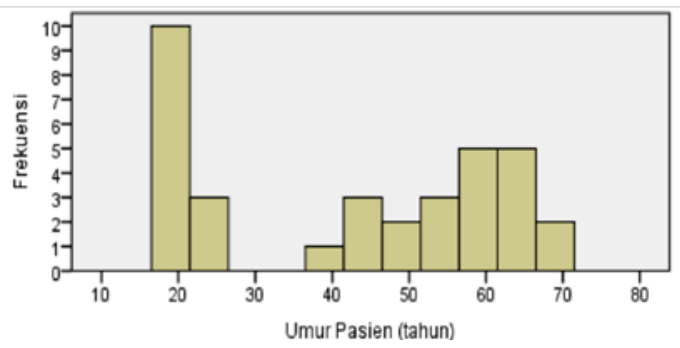

Gambar 1. Histogram sebaran umur pasien

Sebaran usia pasien pada penelitian ini memiliki pola parabolik, dimana 13 dari 34 pasien $(38,2 \%)$ memiliki usia $<30$ tahun (19-22 tahun) dan 8 pasien (23,5\%) memiliki usia >60 tahun (61-68 tahun). Sisanya berusia 30-60 tahun; hanya ada 1 pasien yang berusia 30-40 tahun (Gambar 1 dan Tabel 1). Secara umum, laparotomi karena apendisitis perforata pada penelitian ini lebih banyak dilakukan pada individu berusia $>40$ tahun.

Dalam hal jenis kelamin, dari 34 pasien terdapat 24 (70,6\%) laki-laki dan 10 (29,4\%) perempuan. Karakteristik sampel lainnya berdasarkan data pascaoperasi ialah panjang irisan abdomen yang dibuat dengan kisaran 12-30 cm (rerata 18,9 $\pm 4,5$ $\mathrm{cm}$ ); volume perdarahan perioperatif tercatat berkisar 100-500 cc (rerata $173,5 \pm 88,1$ cc) yang menandakan sedikitnya pasien dengan perdarahan yang mendekati 500 cc; laparatomi berlangsung antara 90-180 menit (rerata 122,5 $\pm 36,2$ menit) dimana $24 \quad(70,6 \%)$ laparatomi berlangsung tidak lebih dari 2 jam, namun ada 7 (20,6\%) kasus yang berlangsung selama 3 jam; dan skala nyeri berkisar antara 7-9 (rerata 8,2 $\pm 0,7$ ).

Kadar hemoglobin yang diperiksa pascaoperasi berkisar 8,8-18,0 $\mathrm{mg} / \mathrm{dL}$ (rerata 12,8 $\pm 2,5 \mathrm{mg} / \mathrm{dL}$ ). Terdapat 9 (26,5\%) pasien memiliki kadar hemoglobin $\leq 10 \mathrm{mg} / \mathrm{dL} ; 5$ pasien termasuk dalam kelompok coklat. Kadar leukosit berkisar 9.600-32.000 / $\mu \mathrm{L} 3$ (rerata 17.961,2 \pm $4.820,7 / \mu \mathrm{L} 3$ ); hanya 1 pasien yang memiliki kadar lekosit $<10.000 / \mu \mathrm{L} 3$. Kadar natrium serum berkisar 128-144 $\mathrm{mmol} / \mathrm{L} \quad$ (rerata 135,3 $\pm 3,7 \mathrm{mmol} / \mathrm{L}$ ), sedangkan kadar kalium serum berkisar 3,2-4,7 mmol/L (rerata 3,8 $\pm 0,4 \mathrm{mmol} / \mathrm{L}$ ).

Tabel 1. Karakteristik demografi dan data praoperatif

\begin{tabular}{lcccccc}
\hline \multirow{2}{*}{ Parameter } & \multicolumn{2}{c}{$\begin{array}{c}\text { Kelompok } \\
\text { kontrol }\end{array}$} & \multicolumn{2}{c}{$\begin{array}{c}\text { Kelompok } \\
\text { coklat }\end{array}$} & \multicolumn{2}{c}{$\begin{array}{c}\text { Seluruh } \\
\text { sampel }\end{array}$} \\
\cline { 2 - 7 } & $\mathrm{n}$ & $\%$ & $\mathrm{n}$ & $\%$ & $\mathrm{n}$ & $\%$ \\
\hline Umur & & & & & & \\
- 19 - 20 tahun & 3 & 8,8 & 5 & 14,7 & 8 & 23,5 \\
- 21 - 30 tahun & 3 & 8,8 & 2 & 5,9 & 5 & 14,7 \\
- 31 - 40 tahun & 0 & 0,0 & 1 & 2,9 & 1 & 2,9 \\
- 41 - 50 tahun & 3 & 8,8 & 2 & 5,9 & 5 & 14,7 \\
- 51 - 60 tahun & 4 & 11,8 & 3 & 8,8 & 7 & 20,6 \\
- 61 - 70 tahun & 4 & 11,8 & 4 & 11,8 & 8 & 23,5 \\
Jenis Kelamin & & & & & & \\
- Laki-laki & 10 & 29,4 & 14 & 41,2 & 24 & 70,6 \\
- Perempuan & 7 & 20,6 & 3 & 8,8 & 10 & 29,4 \\
\hline
\end{tabular}


Histogram untuk durasi IPO pada kelompok kontrol maupun kelompok coklat menunjukkan bahwa keduanya memiliki sebaran normal (Gambar 2). Hasil uji Kolmogorov-Smirnov mempertegas bahwa data pada kedua kelompok menyebar normal secara signifikan (Tabel 2).

Karena durasi IPO terbukti memiliki sebaran normal, maka pengujian hipotesis pada penelitian ini dilakukan dengan uji-t dua sampel independen. Uji-t menghasilkan signifikansi sebesar 0,013. Nilai ini lebih kecil dari nilai ambang 0,05 yang telah ditetapkan sehingga memungkinkan diterimanya hipotesis yang menyatakan bahwa makan coklat mempersingkat durasi IPO setelah laparatomi pada apendisitis perforata. Tabel 3 menunjukkan bahwa pemberian coklat pada penelitian ini dapat mempersingkat durasi IPO hingga rata-rata 8,8 jam, dimana kelompok coklat rata-rata mengalami ileus selama 26,06 $\pm 11,266$ jam, sedangkan kelompok Kontrol rata-rata mengalaminya selama 34,88 $\pm 10,746$ jam.

Dari 17 pasien yang diberi coklat, tidak dijumpai adanya keluhan yang berhubungan dengan pemberian coklat.
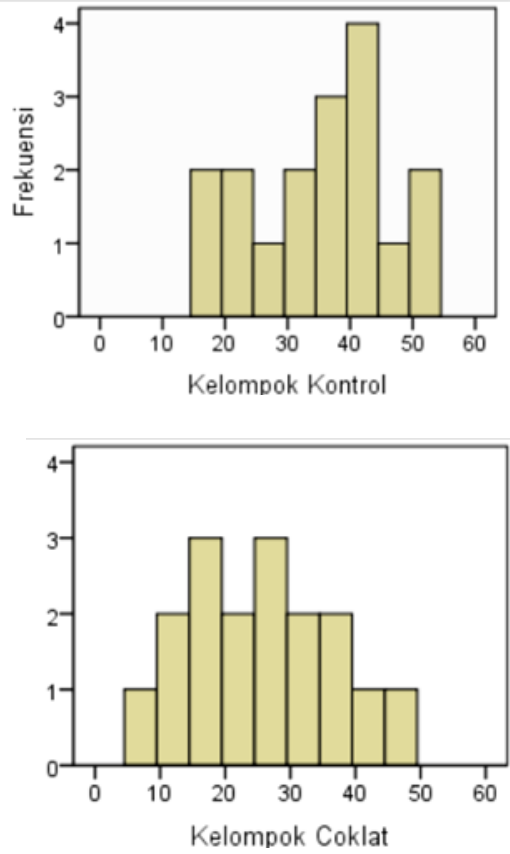

Gambar 2. Sebaran durasi IPO

Tabel 2. Hasil Tes Kolmogorov-Smirnov

\begin{tabular}{cccc}
\hline Kelompok & \multicolumn{3}{c}{ Uji Kolmogorov-Smirnov } \\
\cline { 2 - 4 } & Statistik & df & Sig. \\
\hline Kontrol &, 130 & 17 &, 200 \\
&, 116 & 17 &, 200
\end{tabular}

Tabel 3. Hasil Uji-t 2 sampel independen

\begin{tabular}{ccccccc}
\hline Kelompok & \multicolumn{3}{c}{ Analisis deskriptif } & \multicolumn{2}{c}{$\begin{array}{c}\text { t-test for } \\
\text { equality of means }\end{array}$} \\
\hline Kontrol & Min & Maks & Rerata & SB & t & Sig (1-tailed) \\
Coklat & 17 & 53 & 34,88 & 10,746 & $-2,337$ &, 013 \\
\hline
\end{tabular}

\section{BAHASAN}

Definisi IPO masih kontroversial, terutama menyangkut waktunya, namun secara umum telah diterima bahwa IPO merupakan ileus fisiologik yang terjadi $\leq 72$ jam setelah prosedur pembedahan yang dapat pulih spontan tanpa penanganan khusus. Ileus yang berlangsung $>72$ jam masih dapat dikategorikan sebagai IPO, namun dianggap memiliki latar belakang patofisiologis yang memerlukan penanganan khusus. ${ }^{1}$ Pada penelitian ini, semua pasien memiliki durasi IPO $<72$ jam.
Insidens IPO meningkat pada usia lanjut karena degenerasi struktur organ viseral dan degenerasi neurologik yang menjadikan individu berusia lanjut lebih rentan terhadap penurunan motilitas saluran cerna dan fungsi tubuh lain. ${ }^{2,6}$ Pada penelitian ini terdapat 8 pasien IPO $(23,5 \%)$ berusia $>60$ tahun. Jumlah ini tidak begitu dominan karena relatif banyaknya jumlah pasien berusia muda yaitu 13 pasien $(38,2 \%)$ berusia $<30$ tahun yang dipengaruhi oleh tingginya insidens laparatomi karena apendisitis perforata 
pada usia muda di RSUP Prof. Dr. R. D. Kandou.

Beberapa studi melaporkan predileksi IPO yang bermakna pada jenis kelamin laki-laki, namun faktor risiko ini lebih banyak disebabkan oleh tingginya insidens pembedahan darurat pada laki-laki. ${ }^{12,13}$ Predileksi IPO pada laki-laki nampak pula pada penelitian ini, dimana dari 34 pasien terdapat 24 laki-laki (70,6\%) dan 10 perempuan $(29,4 \%)$.

Riwayat gangguan jalan napas dikaitkan dengan kecenderungan usus mengalami iskemia yang melatarbelakangi patofisiologi IPO. ${ }^{12,13}$ Faktor risiko lain ialah derajat perdarahan serta penurunan kadar hemoglobin dan volume transfusi darah selama periode perioperatif. Faktorfaktor hemostasis vaskuler ini dihubungkan dengan penurunan perfusi jaringan usus yang dapat memperburuk mekanisme patofisiologi pada IPO. ${ }^{6,12-14}$ Terdapat 2 faktor lain yang tidak kalah pentingnya ialah dosis opiat ${ }^{2,14}$ dan sifat prosedur pembedahan itu sendiri, dimana pasien pembedahan darurat serta berdurasi panjang lebih berisiko mengalami IPO. ${ }^{12,13}$ Faktor-faktor risiko di atas merupakan situasi yang umum terjadi pada pasien laparatomi akibat apendisitis perforata. Semua operasi pada penelitian ini dilakukan secara darurat dengan durasi $\geq 90$ menit dan melibatkan penggunaan anastesi umum serta opioid.

Patofisiologi IPO diawali oleh respons neurologik akibat irisan dinding abdomen, diikuti irisan dan perlakuan pada peritoneum maupun organ viseral. Perlakuan-perlakuan ini merangsang nosiseptor dan mekanoreseptor di daerah abdomen yang meneruskan impulsnya ke hipotalamus dan nukleus traktus solitarius. $^{15-18}$ Rangsangan ini mengubah jalur regulasi yang tadinya melalui serabutserabut parasimpatik di sistem saraf enterik (SSE) yang melepas asetilkolin menjadi jalur regulasi simpatetik torakolumbar yang cenderung melepas katekolamin. Hal ini menurunkan tonus dan kontraktilitas otototot polos usus sehingga menimbulkan
IPO $^{19-23}$

Insisi dinding abdomen dan perlakuanperlakuan pada peritoneum maupun usus juga memicu pelepasan mediator-mediator pro-inflamasi, ${ }^{24,25}$ terutama histamin, prostanoid, interleukin-6, dan interleukin$8 .^{26}$ Respons ini terutama diperantarai oleh sel mast ${ }^{25,27-29}$ dan monosit/makrofag. ${ }^{30,31}$ Aktivasi makrofag dipicu oleh pelepasan DAMP (damage-associated molecular patterns) akibat terjadinya cidera seluler mekanik maupun kimiawi, dan pelepasan PAMP (pathogen-associated molecular patterns) akibat meningkatnya permeabilitas dinding usus sehingga memungkinkan translokasi kuman-kuman komensal yang akhirnya menjadi patogen dan melepas mediator-mediator inflamasi. ${ }^{32}$ Gangguan motilitas akibat respons inflamasi terjadi melalui beberapa cara. Pertama, prostaglandin E2 dengan bantuan siklooksignease-2 (COX-2) dan NO menurunkan tonus otot polos dan berefek secara langsung pada penurunan kontraktilitas dinding saluran cerna. ${ }^{26,32,33}$ Kedua, terjadinya edema pada dinding usus yang dilatarbelakangi oleh pemberian cairan intravena berlebihan selama masa perioperatif $^{34}$ yang mengganggu motilitas dengan cara membatasi kontraktilitas miotonik secara mekanik. ${ }^{32,35}$ Ketiga, inflamasi juga memicu pelepasan mediator yang menyebabkan vasokonstriksi lokal pada dinding usus dan menimbulkan iskemia. Penurunan aliran darah arterial akan memperberat terjadinya iskemia dinding usus. Iskemia menimbulkan stres oksidatif yang terbukti dapat mengganggu motilitas usus. Penanganan stres oksidatif (misalnya dengan CO-releasing molecules) dapat mencegah terjadinya IPO. ${ }^{36}$

Reseksi usus dan anastomosis menyebabkan diskontinuitas pada pleksus Auerbach dan Meissner. Regenerasi jaringan saraf memakan waktu berhari-hari sehingga kerusakan ini akhirnya menjadi barier mekanik terhadap rambatan peristaltik, terutama gelombang kontraksi propagatif ke arah distal. ${ }^{37,38}$ Intervensi bedah, puasa sebelum pembedahan, dan 
tertundanya diet oral setelah pembedahan dapat memodulasi sejumlah hormon dan neuropeptida yang penting dalam pengendalian motilitas saluran cerna seperti motilin, $^{39}$ substansi-P, ${ }^{40,41}$ dan VIP. ${ }^{41,42}$ Ketidaksetimbangan elektrolit dapat memperpanjang durasi IPO akibat penurunan intensitas kontraksi, ${ }^{43-45}$ termasuk hipokalemia, ${ }^{46}$ hipokalsemia dan hipermagnesemia, ${ }^{2}$ serta hiponatremia. ${ }^{6}$ Pemberian opioid eksogen menekan motilitas usus ${ }^{2,6,47,48}$ yang diperburuk oleh diproduksinya opioid endogen akibat stres perioperatif. ${ }^{49}$ Opioid menekan SSP secara langsung dan memiliki efek samping terhadap saluran cerna melalui agonis pada reseptor $\mu$-opioid perifer ${ }^{50}$ yang menghambat pelepasan asetilkolin; ${ }^{51}$ pemberian antagonis reseptor $\mu$-opioid perifer dapat mempersingkat durasi IPO. ${ }^{52}$ Beberapa zat yang diberikan selama masa perioperatif dapat memengaruhi fungsi saluran cerna secara bermakna, misalnya cairan intravena $^{53}$ dan beberapa antiemetik maupun prokinetik $^{54}$ dengan mekanisme kerja yang belum jelas. Resusitasi cairan berlebihan dapat menyebabkan peningkatan tekanan hidrostatik intravaskuler sehingga terjadi edema yang membatasi kontrakti-litas miotonik secara mekanik. ${ }^{32,34,35}$

Ileus pada kasus apendisitis perforata mungkin sudah terjadi sebelum tindakan medis dan laparatomi dilakukan karena penyebaran eksudat dari lumen apendiks yang dapat menyebabkan iritasi peritoneum dan memicu kaskade inflamasi. ${ }^{15}$ Selain itu, adhesi pada apendisitis perforata dapat terjadi sejak apendiks mengalami inflamasi dan nekrosis. Meskipun derajat adhesi tidak seberat adhesi akibat pembedahan, namun adhesi ini cukup kompeten dalam menghambat secara mekanik pada pergerakan usus yang memang sudah melemah akibat peritonitis. Adhesi dapat diperberat oleh terlepasnya eksudat fibrin saat perforasi. ${ }^{55,56}$ Selain inflamasi dan adhesi, pasien apendisitis perforata umumnya mengalami deplesi volume cairan tubuh sehingga harus diberi resusitasi cairan preoperatif yang bila berlebihan dapat memperberat terjadinya ileus akibat edema dinding usus. ${ }^{57}$

Coklat, dalam berbagai bentuk, sering digunakan untuk mengobati berbagai penyakit dan meningkatkan vitalitas sejak abad ke-16. Theobroma cacao ialah nama Latin tanaman coklat yang berarti makanan dari Tuhan. Kata coklat berasal dari kata chocolatl, xocolatl atau tsocolatl yang berarti air pahit yang menggambarkan bahwa dulu coklat tetap diminum karena khasiatnya yang tinggi meskipun rasanya pahit. ${ }^{11,58,59}$ Bangsa Aztec menggunakan coklat juga untuk meredakan rasa kembung dan memperlancar buang air besar ${ }^{59,60}$ yang menunjukkan efek positif coklat dalam meningkatkan peristaltik.

Coklat mengandung teobromin, metilxantin dan kalsium; keberadaan ketiga bahan aktif ini dalam satu sediaan mendasari peran unik coklat dalam mengatasi IPO. Respons neurologik pada IPO hanya dapat ditekan dengan pemberian obat atau bahan yang menekan aktivitas nosiseptik nervus vagus di perifer, namun tidak menghambat aktivitas saraf di sentral sehingga instruksi motorik tetap diberikan oleh SSP dalam bentuk aktivitas parasimpatis (karena telah ditekannya aktivitas nervus vagus). Usmani et al. ${ }^{61}$ membuktikan bahwa teobromin dapat menghambat aktivitas sensorik nervus vagus melalui inhibisi langsung terhadap depolarisasinya. Schroder et al ${ }^{62}$ membuktikan bahwa metilxantin dapat meningkatkan aktivitas hIK (human intermediateconductance, Ca2+-activated $\mathrm{K}+$ channel) yaitu salah satu saluran yang memerantarai repolarisasi sel-sel saraf pada manusia. Melalui aktivasi hIK, metilxantin menyebabkan hiperpolarisasi membran sel saraf dengan potensial membran berkisar antara -18 hingga $-56 \mathrm{mV}$, yang membuatnya lebih sulit menghantarkan rangsangan. Efek ini hanya bisa dicapai bila kadar ion kalsium intrasel mencapai 60 $\mathrm{nM}^{62}$ dan coklat merupakan salah satu makanan yang menyediakan metilxantin dan kalsium sekaligus dalam satu sediaan.

Aktivitas anti-inflamasi dari flavonoid dalam coklat dapat mengatasi iskemia dan menghambat mediator inflamasi serta 
aktivitas leukosit. Flavonol (flavonoid pada coklat) dapat mengaktivasi NO yang kemudian meningkatkan konsentrasi cGMP (cyclic glutamat monophosphate) sehingga menyebabkan relaksasi otot polos pembuluh darah dan terjadi vasodilatasi. Hal ini dapat meningkatkan aliran darah ke sirkulasi saluran cerna serta meningkatkan availabilitas nutrisi dan oksigen yang diperlukan dalam penyembuhan luka sehingga respons inflamasi dapat berjalan efektif dan segera diakhiri. NO juga mencegah adhesi dan migrasi leukosit serta adhesi dan proliferasi platelet. ${ }^{58,63}$ Epikatekin dalam coklat terbukti menghambat produksi tumor necrosis factor alpha (TNF $\alpha)$, interleukin 6, dan prostaglandin E2 oleh makrofag secara efektif $^{64}$ serta menghambat infiltrasi netrofil ke daerah lesi intestinal ${ }^{65}$ sehingga menghambat proses inflamasi lebih lanjut. Efek epikatekin ini dipengaruhi oleh kadar teobromin pada coklat $^{66}$ yang sekali lagi membuktikan superioritas coklat karena memiliki bahan-bahan aktif ini secara bersamaan. Flavonoid juga dapat menurunkan tonus sfingter sehingga membantu propulsi isi lumen ke arah distal saluran cerna. Hal ini dapat mempercepat resolusi ileus paralitik pada periode pascaoperasi. $^{67}$

Meskipun demikian, terjadinya IPO tidak semata-mata disebabkan oleh respons inflamasi dan neurologik. Terdapat berbagai faktor lain yang tidak dapat dihambat melalui pemberian coklat, antara lain perdarahan, resusitasi cairan, pemberian opioid, defisit nutrisi akibat tertundanya diet oral, penyakit-penyakit penyerta, serta faktor-faktor fisik seperti reseksi dan anastomosis. Di samping itu, latar belakang demografis juga memengaruhi terjadinya IPO, terutama usia pasien. Oleh karena itu dapat dimaklumi bahwa pemberian coklat tidak selalu memberi hasil seperti yang diharapkan, terutama pada individu yang memiliki salah satu faktor risiko di atas.

Hasil-hasil dalam penelitian ini membuktikan bahwa pemberian coklat sejak 6 jam pascaoperasi dapat menurunkan
IPO pada laparatomi akibat apendisitis perforata hingga \pm 8 ,8 jam.

Terdapat beberapa temuan yang perlu dikaji lebih jauh, yakni: 1) adanya pasien yang tidak mengalami pemendekan durasi IPO meskipun mereka diberi coklat; dan 2) adanya pasien yang durasi ileusnya tetap singkat meskipun tidak diberi coklat. Sebelum membahas kedua hal tersebut, tentunya penting untuk menentukan batas waktu berapa lama durasi IPO dapat dianggap normal dan berapa lama dikatakan singkat, setidaknya pada penelitian ini. Tujuh belas pasien pada kelompok yang tidak diberi coklat memiliki durasi ileus antara 17- 53 jam (rerata $34,88 \pm 10,746$ jam) pascaoperasi, artinya sebuah IPO baru benar-benar dapat dikatakan singkat bila berlangsung tidak lebih dari 34,88-10,746 atau 24 jam. Demikian pula, IPO pada penelitian ini dikatakan tidak singkat bila berlansung lebih dari 34,88+ 10,746 atau 45 jam.

Terdapat 1 pasien pada kelompok coklat yang tetap memiliki durasi IPO $>45$ jam (Sampel ke-25), yaitu seorang laki-laki 62 tahun dengan durasi ileus 48 jam. Dipihak lain, terdapat 4 pasien pada kelompok kontrol yang memiliki durasi IPO <24 jam meskipun tidak diberi coklat; salah satunya seorang perempuan berusia 19 tahun (sampel ke-5) yang merupakan 1 dari 3 pasien pada kelompok kontrol yang berada dalam kelompok usia $\leq 20$ tahun sedangkan 3 lainnya pada kelompok umur 21-30 tahun (sampel ke-16 berusia 22 tahun dengan durasi IPO 21 jam; sampel ke-27 berusia 22 tahun dengan durasi IPO 18 jam; dan sampel ke-33 berusia 21 tahun dengan durasi IPO 23 jam).

Sampel ke-25 ialah pasien yang menjalani laparatomi dengan irisan abdomen sepanjang $15 \mathrm{~cm}$, perdarahan hanya 150 cc, durasi operasi hanya 90 menit, dan hasil-hasil pemeriksaan laboratorium yang masih dalam batas normal untuk sebuah apendisitis perforata. Variabel yang nampaknya berpengaruh pada kasus ini ialah usia pasien $>60$ tahun. Meskipun IPO dapat pula dipengaruhi oleh faktor-faktor yang tidak dievaluasi dalam 
penelitian ini (seperti riwayat penyakit sistemik, dosis obat-obat anastesi, dan perlakuan-perlakuan pada organ viseral), namun temuan ini mengisyaratkan bahwa faktor usia memiliki peran yang sangat penting dalam menurunkan respons IPO terhadap pemberian coklat. Terdapatnya 3 pasien lain berusia 21 dan 22 tahun dengan durasi IPO singkat meskipun tidak diberi coklat mempertegas fakta bahwa usia merupakan faktor yang sangat memengaruhi kejadian IPO.

Berbagai penelitian berskala besar telah membuktikan hal tersebut. ${ }^{2,6}$ Penelitian-penelitian lain juga memberi bukti bagaimana usia dapat memengaruhi fungsi saluran cerna sehingga melatarbelakangi terjadinya IPO. Faktor penuaan dilaporkan memengaruhi peristalsis faring, relaksasi sfingter esofagus superior, kontraksi otot suprahioid, serta ekskursi deglutitif dari laring dan tulang hioid; perubahan-perubahan ini memengaruhi kinematika bolus dan dinamika gerakan menelan pada faring. ${ }^{68}$ Dejeager et al. ${ }^{69}$ membuktikan bahwa penurunan daya dorong lidah, penurunan amplitudo kontraksi dinding faring, dan penurunan daya menelan faring pada individu berusia lanjut menyebabkan retensi makanan pada sinus-sinus piriformis dan valekula. Dibuktikan pula bahwa penuaan mengakibatkan penurunan aktivitas peristalsis dan peningkatan kontraksi-kontraksi nonpropulsif di esofagus ${ }^{70,71}$ serta penurunan peristalsis postprandial dan kontraktilitas gaster. $^{72}$ Mengenai usus halus, sebuah penelitian melaporkan bahwa penuaan hanya menyebabkan penurunan ringan dalam frekuensi kontraksi postprandial dan kontraksi-kontraksi propagatif, $^{73}$ namun sebuah studi multisenter yang melibatkan 172 orang dewasa sehat dan menggunakan kapsul motilitas nirkabel melaporkan bahwa penuaan menurunkan waktu transit usus halus secara bermakna, yakni \pm 12 menit untuk setiap 10 tahun pertambahan umur. $^{74}$ Meskipun insidens konstipasi meningkat pesat seiring bertambahnya usia, efek penuaan pada motilitas dan waktu transit kolon masih disimpulkan secara berbeda-beda dalam beberapa studi terakhir. $^{70,74,75}$ Penuaan juga menyebabkan penurunan tonus basal dan tonus maksimum sfingter ani serta penurunan elastisitas rektum. ${ }^{70,73,74,76}$

Berbagai penurunan kemampuan propagatif di atas didasari oleh perubahanperubahan degeneratif yang umumnya bersifat ireversibel sehingga dapat dimaklumi bila pemberian coklat tidak selalu memberi hasil yang memuaskan dalam mempersingkat IPO pada pasien apendisitis perforata berusia lanjut.

Sebaliknya, 3 pasien pada kelompok kontrol yang tidak mengalami pemanjangan durasi IPO meskipun tidak diberi coklat mengisyaratkan bahwa resolusi IPO dapat berlangsung dengan normal bila faktor-faktor degeneratif di atas tidak ditemukan. Tindakan-tindakan aktif untuk mempersingkat durasi IPO mungkin tidak diperlukan pada kelompok usia dewasa muda. Meskipun demikian, pengaruh langsung penuaan terhadap durasi IPO maupun pengaruh langsungnya pada efektifitas pemberian coklat tidak dapat serta merta disimpulkan dalam penelitian ini mengingat kurangnya jumlah sampel.

\section{SIMPULAN}

Dari hasil penelitian ini pemberian coklat 6 jam setelah laparotomi pada kasuskasus apendisitis perforata dapat mempersingkat durasi IPO hingga rata-rata 8,8 jam, terutama dalam hal terjadinya flatus pertama. Tidak ada efek samping bermakna yang dilaporkan.

\section{SARAN}

Perlu dilakukan studi-studi lebih lanjut dengan metode pemeriksaan ileus yang lebih obyektif, misalnya dengan mengukur aktivitas elektrik usus, mengukur tekanan intraluminal, atau memanfaatkan teknikteknik pencitraan seperti foto Rontgen dan CT-scan.

Pada penelitian lanjut perlu memperhitungkan lamanya perforasi dan ada tidaknya ileus pada pasien apendisitas perforata sebelum mereka menjalani 
laparotomi, mengamati dosis coklat yang paling efektif untuk setiap kelompok usia, dan menerapkan teknik sampling berpasangan untuk mengamati efektifitas pemberian coklat pada minimal dua sampel dengan karakteristik yang sama agar dapat dipelajari bagaimana efektifitas coklat dipengaruhi oleh berbagai faktor lain.

\section{DAFTAR PUSTAKA}

1. Vather R, O’Grady G, Bissett IP, Dinning PG. Pathophysiologic, translational and clinical aspects of postoperative ileus - a review. Proceedings of the Australian Physiological Society. 2013;44:85-99.

2. Kronberg U, Kiran RP, Soliman MSM, Hammel JP, Galway U, Coffey JC, Fazio VW. A characterization of factors determining postoperative ileus after laparoscopic colectomy enables the generation of a novel predictive score. Annals of Surgery. 2011;253:78-81.

3. Goldstein JL, Matuszewski KA, Delaney CP, Senagore A, Chiao EF, Shah M, et al. Inpatient economic burden of postoperative ileus associated with abdominal surgery in the United States. P \& T 2007;32:82-90.

4. Kiecolt-Glaser JK, Page GG, Marucha PT, MacCallum RC, Glaser R. Psychological influences on surgical recovery: perspectives from psychoneuroimmunology. American Psychology. 1998;53:1209.

5. Harrison S, Mahawar K, Brown D, Boobis L, Small P. Acute appendicitis presenting as small bowel obstruction: two case reports. Cases Journal. 2009;2: 9106. DOI: 10.1186/1757-1626-2-9106.

6. Vather R, Bissett IP. Risk factors for the development of prolonged postoperative ileus following elective colorectal surgery. Int J Colorectal Dis. 2013;28(10):1385-91.

7. Omari AH, Khammash MR, Qasaimeh GR, Shammari AK, Yaseen MKB, Hammori SK. Acute appendicitis in the elderly: risk factors for perforation. World Journal of Emergency Surgery. 2014;9:6.

8. Tandililing S. Perbandingan efektifitas makan coklat dan mengunyah permen karet dalam mempersingkat durasi ileus postoperatif [Karya Akhir PPDS Bedah].
Manado: FK Unsrat, 2013.

9. Sipayung EJ. Perbandingan efektifitas makan coklat dengan mengunyah permen karet dalam mempersingkat durasi ileus postoperatif pada laparatomi karena trauma abdomen [Karya Akhir PPDS Bedah]. Manado: FK Unsrat, 2013.

10. Fauci AS, Braunwald E, Kasper DL, Hauser SL, Longo DL, Jameson JL, et al, editors. Harrison's Manual of Medicine (17th ed.). New York: McGraw-Hill, 2009; p. 3-10.

11. Verna $\mathbf{R}$. The history and science of chocolate. Malaysian Journal of Pathology. 2013;35(2):111-21.

12. Millan M, Biondo S, Fraccalvieri D, Frago R, Golda T, Kreisler E. Risk factors for prolonged postoperative ileus after colorectal cancer surgery. World Journal of Surgery. 2012;36:179-85.

13. Chapuis PH, Les Bokey MS, Keshava A, Rickard MJFX, Stewart P, Young CJ, et al. Risk factors for prolonged ileus after resection of colorectal cancer: An observational Study of 2400 consecutive patients. Annals of Surgery. 2013;257: 909-15.

14. Artinyan A, Nunoo-Mensah JW, Balasubramaniam S, Gauderman J, Essani R, Gonzalez-Ruiz C, et al. Prolonged postoperative ileus definition, risk factors, and predictors after surgery. World Journal of Surgery. 2008;32: 1495-500.

15. Thayer JF, Sternberg EM. Neural aspects of immunomodulation: focus on the vagus nerve. Brain Behavioral Immunology. 2010;24:1223-8.

16. Julius D, Basbaum AI. Molecular mechanisms of nociception. Nature. 2001;413:203-10.

17. Cervero F, Laird J. Visceral pain. Lancet. 1999;353:2145-8.

18. Berthoud H-R, Neuhuber WL. Functional and chemical anatomy of the afferent vagal system. Autonomic Neuroscience. 2000;85:1-17.

19. Tache Y, Monnikes H, Bonaz B, Rivier J. Role of CRF in stress-related alterations of gastric and colonic motor functions. Annals of New York Academy of Science. 1993;697:233-43.

20. Zittel TT, De Giorgio R, Brecha NC, Sternini C, Raybould HE. Abdominal surgery induces c-fos expression in the 
nucleus of the solitary tract in the rat. Neuroscience Letters. 1993;159:79-82.

21. Gourcerol G, Gallas S, Mounien L, Leblanc I, Bizet P, Boutelet I, et al. Gastric electrical stimulation modulates hypothalamic corticotropin-releasing factor-producing neurons during postoperative ileus in rat. Neuroscience. 2007;148:775-81.

22. Kreiss C, Toegel S, Bauer AJ. Alpha-2adrenergic regulation of NO production alters postoperative intestinal smooth muscle dysfunction in rodents. American Journal of Physiology Gastrology and Liver Physiology. 2004; 287:G658-66.

23. Yokotani K, Okuma Y, Nakamura K, Osumi Y. Release of endogenous acetylcholine from a vascularly perfused rat stomach in vitro; inhibition by M3 muscarinic autoreceptors and alpha-2 adrenoceptors. Journal of Pharmacology Exp Therapies. 1993;266:1190-5.

24. Kalff JC, Turler A, Schwarz NT, Schraut WH, Lee KKW, Tweardy DJ, et al. Intra-abdominal activation of a local inflammatory response within the human muscularis externa during laparotomy. Annals of Surgery. 2003;237:301-15.

25. The FO, Bennink RJ, Ankum WM, Buist MR, Busch O, Gouma DJ, et al. Intestinal handling-induced mast cell activation and inflammation in human postoperative ileus. Gut. 2008;57:33-40.

26. Kreiss C, Birder LA, Kiss S, VanBibber MM, Bauer AJ. COX-2 dependent inflammation increases spinal Fos expression during rodent postoperative ileus. Gut. 2003;52:527-34.

27. de Jonge WJ, van der Coelen D, Bennink RJ, Reitsma PH, van Deventer SJ, Van den Wijngaard RM, et al. Mast cell degranulation during abdominal surgery initiates postoperative ileus in mice. Gastroenterology. 2004;127:53545.

28. Roelofsen H, Soroka CJ, Keppler D, Boyer JL. Cyclic AMP stimulates sorting of the canalicular organic anion transporter (Mrp2/cMoat) to the apical domain in hepatocyte couplets. Journal of Cellular Science. 1998;111:1137-45.

29. Echtenacher B, Mannel DN, Hültner L. Critical protective role of mast cells in a model of acute septic peritonitis. Nature.
1996;381:75-7.

30. Kalff JC, Buchholz BM, Eskandari MK, Hierholzer C, Schraut WH, Simmons $\mathbf{R L}$, et al. Biphasic response to gut manipulation and temporal correlation of cellular infiltrates and muscle dysfunction in rat. Surgery. 1999;126: 498-509.

31. Kalff JC, Carlos TM, Schraut WH, Billiar TR, Simmons RL, et al. Surgically induced leukocytic infiltrates within the rat intestinal muscularis mediate postoperative ileus. Gastroenterology. 1999;117:378-87.

32. Boeckxstaens GE, de Jonge WJ. Neuroimmune mechanisms in postoperative ileus. Gut. 2009; 58:130011.

33. Kalff JC, Schraut WH, Billiar TR, Simmons RL, Bauer AJ. Role of inducible nitric oxide synthase in postoperative intestinal smooth muscle dysfunction in rodents. Gastroenterology. 2000;118:316-27.

34. Lobo DN, Bostock KA, Neal KR, Perkins AC, Rowlands BJ, Allison SP. Effect of salt and water balance on recovery of gastrointestinal function after elective colonic resection: a randomised controlled trial. Lancet. 2002;359:18128.

35. Holte K, Sharrock N, Kehlet $\mathbf{H}$. Pathophysiology and clinical implications of perioperative fluid excess. British Journal of Anaesthesiology. 2002;89:622-32.

36. de Backer O, Elinck E, Blanckaert B, Leybaert L, Motterlini R, Lefebvre RA. Water-soluble CO-releasing molecules reduce the development of postoperative ileus via modulation of MAPK/HO-1 signalling and reduction of oxidative stress. Gut. 2009;58:347-56.

37. Mochiki E, Asao T, Kuwano $\mathbf{H}$. Gastrointestinal motility after digestive surgery. Surgery Today. 2007;37:102332.

38. Roberts JP, Benson MJ, Rogers J, Deeks JJ, Williams NS. Characterization of distal colonic motility in early postoperative period and effect of colonic anastomosis. Digestive Dis Science. 1994;39:1961-7.

39. Cullen JJ, Kelly KA. Gastrointestinal peptide hormones during postoperative 
ileus. Digestive Dis Science. 1994;39:1179-84.

40. Holzer P, Holzer-Petsche U. Tachykinins in the gut. Part I. Expression, release and motor function. Pharmacology and Therapy. 1997;73:173-217.

41. Espat NJ, Cheng G, Kelley MC, Vogel SB, Sninsky CA, Hocking MP. Vasoactive intestinal peptide and substance $P$ receptor antagonists improve postoperative ileus. Jornal of Surgery Res. 1995;58:719-23.

42. Delgado M, Ganea D. Vasoactive intestinal peptide: a neuropeptide with pleiotropic immune functions. Amino Acids. 2013;45(1):25-39.

43. Hall JE. Guyton and Hall Textbook of Medical Physiology (12th ed.). Philadelphia: Elsevier-Saunders, 2011.

44. Behm B, Stollman N. Postoperative ileus: etiologies and interventions. Clinical Gastroenterology and Hepatology. 2003; 1:71-80.

45. Bauer AJ, Boeckxstaens GE. Mechanisms of postoperative ileus. Neurogastroenterology Motility. 2004;16:54-60.

46. Lowman RM. The potassium depletion states and postoperative ileus. Radiology. 1971;98:691-4.

47. Pappagallo M. Incidence, prevalence, and management of opioid bowel dysfunction. American Journal of Surgery. 2001;182:S11-8.

48. Frantzides CT, Cowles V, Salaymeh B, Tekin E, Condon RE. Morphine effects on human colonic myoelectric activity in the postoperative period. American Journal of Surgery. 1992;163:144-9.

49. Yoshida S, Ohta J, Yamasaki K, Kamei H, Harada Y, Yahara T, et al. Effect of surgical stress on endogenous morphine and cytokine levels in the plasma after laparoscopoic or open cholecystectomy. Surgery and Endoscopy. 2000;14:137-40.

50. Bauer A, Boeckxstaens G. Mechanisms of postoperative ileus. Neurogastroenterology and Motility. 2004;16:54-60.

51. Taguchi A, Sharma N, Saleem RM, Sessler DI, Carpenter RL, Seyedsadr M, et al. Selective postoperative inhibition of gastrointestinal opioid receptors. N Engl J Med. 2001;345: 93540.

52. Vaughan-Shaw P, Fecher I, Harris S,
Knight J. A Meta-analysis of the Effectiveness of the opioid receptor antagonist Alvimopan in reducing hospital length of stay and time to GI recovery in patients enrolled in a standardized accelerated recovery program after abdominal surgery. Diseases of Colon and Rectum. 2012; 55:611-20.

53. Rahbari N, Zimmermann J, Schmidt T, Koch M, Weigand M, Weitz J. Metaanalysis of standard, restrictive and supplemental fluid administration in colorectal surgery. British Journal of Surgery. 2009; 96:331-41.

54. Traut U, Brugger L, Kunz R, PauliMagnus C, Haug K, Bucher $\mathrm{H}$, et al. Systemic prokinetic pharmacologic treatment for postoperative adynamic ileus following abdominal surgery in adults. Cochrane Database Systematic Reviews 2009; DOI: 10.1002/14651858.CD004930.pub3.

55. Ransom HK. Complication associated with appendicitis. American Journal of Surgery. 1942;56(1):102-7.

56. Dudley GS. Paralytic ileus as a complication of acute appendicitis. Annals of Surgery. 1926;84(5):729-34.

57. Bhandari L, Mohandas PG. Appendicitis as a cause of intestinal strangulation: a case report and review. World Journal of Emergency Surgery. 2009;4:34. DOI:10.1186/1749-7922-4-34.

58. Corti R, Flammer AJ, Hollenberg NK, Luscher TF. Cocoa and cardiovascular health. Circulation. 2009;119:1433-41. DOI:

10.1161/circulationaha.108.827022.

59. Lippi D. Chocolate in history: food, medicine, medi-food. Nutrients. 2013;5: 1573-84. DOI: 10.3390/nu5051573.

60. Wilson PK. Centuries of seeking chocolate's medicinal benefits. Lancet. 2010;376:158-9.

61. Usmani OS, Belvisi MG, Patel HJ, Crispino N, Birrell MA, Korbonits M, et al. Theobromine inhibits sensory nerve activation and cough. FASEB Journal Express Article. 2004. DOI: 10.1096/fj.04-1990fje.

62. Schrøder RL, Jensen BS, Strøbaek D, Olesen SP, Christophersen P. Activation of the human, intermediateconductance, $\mathrm{Ca} 2+$-activated $\mathrm{K}+$ 
channel by methylxanthines. Pflugers

Archives. 2000;440(6):809-18.

63. van den Bogaard B, Draijer $R$, Westerhof $B E$, van den Meiracker $A H$, van Montfrans GA, van den Born BJH. Effects on peripheral and central blood pressure of cocoa with natural or highdose theobromine: a randomized, double-blind crossover trial. Hypertension. 2010;56:839-46.

64. Wang H, Cao ZR. Anti-inflammatory effects of (-)-epicatechin in lipopolysaccharide-stimulated raw 264.7 macrophages. Tropical Journal of Pharmaceutical Research. 2014;13(9): 1415-9.

65. Vasconcelos PCP, Seito LN, Di Stasi LC, Lima CAH, Pellizzon CH. Epicatechin used in the treatment of intestinal inflammatory disease: an analysis by experimental models. Evidence-Based Complementary and Alternative Medicine, 2012. Article ID: 508902; 12 pages. DOI:10.1155/2012/508902.

66. Yamamoto T, Takahashi H, Suzuki K, Hirano A, Kamei M, Goto T, et al. Theobromine enhances absorption of cacao polyphenol in rats. Bioscience, Biotechnology, and Biochemistry. 2014; 78(12):2059-63.

67. Castell DO. Diet and the lower esophageal sphincter. American Journal of Clinical Nutrition. 1975;28:1296-8.

68. Bardan E, Kern M, Arndorfer RC, Hofmann C, Shaker R. Effect of aging on bolus kinematics during the pharyngeal phase of swallowing. Am J
Physiol Gastrointest Liver Physiol. 2006;290:G458-G465. DOI: 10.1152/ ajpgi.00541.2004.

69. Dejaeger E, Pelemans W, Ponette E, Joosten E. Mechanisms involved in postdeglutition retention in the elderly. Dysphagia. 1997;12:63-7.

70. O'Mahony D, O'Leary P, Quigley EM. Aging and intestinal motility: a review of factors that affect intestinal motility in the aged. Drugs Aging. 2002;19:515-27.

71. Gregersen H, Pedersen J, Drewes AM. Deterioration of muscle function in the human esophagus with age. Dig Dis Sci. 2008;53:3065-70.

72. Shimamoto C, Hirata I, Hiraike Y, Takeuchi N, Nomura T, Katsu $K$. Evaluation of gastric motor activity in the elderly by electrogastrography and the (13) C-acetate breath test. Gerontology. 2002;48:381-6.

73. Firth M, Prather CM. Gastrointestinal motility problems in the elderly patient. Gastroenterology. 2002;122:1688-1700.

74. Saad RJ, Semler JR, Wilding GE, Chey WD. The effects of age on regional and whole gut transit times in healthy adults. Gastroenterol. 2010;138:S-127.

75. Bouras EP, Tangalos EG. Chronic constipation in the elderly. Gastroenterol Clin North Am. 2009;38:463-80.

76. Fox JC, Fletcher JG, Zinsmeister AR, Seide B, Riederer SJ, Bharucha AE. Effect of aging on anorectal and pelvic floor functions in females. Dis Colon Rectum. 2006;49:1726-35. 